\title{
Analisis Miskonsepsi Siswa Kelas V dalam Menyelesaikan Masalah Bangun Ruang Berdasarkan Gender Di SD IT Mutiara Insan Sorong
}

\author{
Lisa Dewi Ramadany
}

Guru SD IT Mutiara Insan Sorong, Indonesia

$\bowtie$ E-mail: lisadewiramadany09@gmail.com

\begin{abstract}
Abstrak
Struktur kognitif yang ada pada diri siswa tidak sesuai dengan konsepsi yang dikemukakan para ahli di bidangnya dapat dikategorikan sebagai miskonsepsi, sehingga antara miskonsepsi dengan gaya kognitif siswa saling berkaitan. Setiap siswa memiliki gaya kognitif yang berbeda termasuk gender. Penelitian yang dilakukan bertujuan untuk menggambarkan miskonsepsi siswa dalam menyelesaikan permasalahan bangun ruang berdasarkan gender serta faktor penyebab miskonsepsi. Jenis penelitian ini adalah penelitian deskriptif dengan pendekatan penelitian kulitatif. Sampel dalam penelitian ini merupakan siswa kelas V SD IT Mutiara Insan Sorong tahun ajaran 2019/2020 sebanyak 6 orang. Subjek dalam penelitian ini sebanyak 4 orang yang dipilih berdasarkan tes diagnostik. Instrumen yang digunakan dalam penelitian ini adalah tes diagnostik dan wawancara untuk mengetahui penyebab miskonsepsi. Hasil penelitian menunjukkan bahwa siswa laki-laki tidak teridentifikasi miskonsepsi, sedangkan siswa perempuan teridentifikasi sebanyak 3 orang. Siswa mengalami miskonsepsi bukan pada materi bangun ruang, akan tetapi pada proses perhitungan perkalian dan pembagian. Penyebab miskonsepsi yang dialami oleh siswa adalah prakonsepsi, pemikiran asosiatif siswa sendiri, pengalaman belajar, dan kurangnya penekanan pada materi yang dibutuhkan siswa.
\end{abstract}

Kata Kunci: Miskonsepsi siswa; gender; bangun ruang.

\begin{abstract}
Cognitive structures that exist in students are not in accordance with the conceptions put forward by experts in their fields can be categorized as misconceptions, so that the misconceptions with students' cognitive styles are interrelated. Each student has a different cognitive style including gender. The research conducted aims to describe the students' misconceptions in solving the problem of building space based on gender and the causes of misconceptions. This type of research is a descriptive study with a skinative research approach. The sample in this study were 6th grade students of SD IT Mutiara Insan Sorong in the 2019/2020 school year as many as 6 people. Subjects in this study were 4 people selected based on diagnostic tests. The instruments used in this study were diagnostic tests and interviews to find out the cause of misconception. The results showed that male students were not identified as misconceptions, while female students were identified as many as 3 people. Students experience misconceptions not in the material of building space, but in the process of calculating multiplication and division. The causes of misconceptions experienced by students are preconceptions, students' own associative thinking, learning experiences, and lack of emphasis on the material students need.
\end{abstract}

Keywords : Student misconceptions; gender; bangun ruang. 


\section{PENDAHULUAN}

Tujuan pembelajaran matematika di SD antara lain agar siswa memiliki kemampuan untuk berpikir kritis, sistematis, logis, analitis, dan kreatif (Rosmalia, 2016). Pembelajaran matematika dengan tuntutantuntutan tersebut memberikan dampak negatif tersendiri diantaranya kurangnya minat belajar matematika di kelas. Salah satu penyebab minimnya minat belajar siswa terhadap matematika adalah anggapan siswa bahwa matematika merupakan salah satu pelajaran yang sulit dimengerti sehingga menjadi momok dalam pembelajaran (Farida, 2016).

Anggapan negatif siswa terhadap pelajaran matematika bukan tanpa sebab, hal ini dikarenakan pembelajaran matematika yang menekankan pemahaman terhadap konsep-konsep mulai dari konsep yang sederhana hingga pada konsep yang abstrak (Asbar, 2017). Konsep-konsep dalam matematika saling berhubungan antara konsep yang satu dengan lainnya, sehingga apabila salah satu konsep tidak dipahami dengan baik maka akan berpengaruh terhadap pemahaman konsep lainnya. Pemahaman terhadap konsep-konsep dasar sangat diperlukan guna memahami konsep yang lebih rumit.

Menurut teori konstruktivistik konsep awal mengenai suatu fenomena telah dibangun oleh anak sebelum memasuki usia sekolah berdasarkan pengalaman interkasi dengan lingkungan sekitarnya (Budiningsih, 2015). Konsep awal yang dimiliki siswa tentang suatu objek disebut prakonsepsi (Rosmalia, 2016). Teori konstruktivistik didukung oleh para peneliti pendidikan yang sepakat bahwa konsepsi awal telah dimiliki dan dibawa siswa ketika memasuki kelas formal, dimana konsepsi awal tersebut terkadang sama dan terkadang berbeda dengan konsep yang disepakati secara umum (Pesman \& Eryilmaz, 2010).

Ketidaksesuaian antara konsep awal siswa dengan konsepsi sebenarnya akan mempengaruhi proses pembelajaran formal dimana hal tersebut berdampak pada interpretasi ilmu yang diajarkan guru dan sifatnya sukar dirubah (Pesman \& Eryilmaz, 2010). Keadaan dimana terjadinya ketidaksesuaian tersebut mengakibatkan siswa meyakini benar konsep yang salah atau disebut dengan miskonsepsi (Hidayat, 2014). (Pesman \& Eryilmaz, 2010) mengemukakan bahwa miskonsepsi memiliki dampak kepada pemahaman konsep siswa, dan harus diatasi agar siswa dapat memahami konsep ilmu pengetahuan secara efektif. Tingkat pemahaman konsep berkaitan dengan hasil belajar siswa. Semakin baik tingkat pemahaman konsep, akan menghasilkan hasil belajar yang baik pula.

Hasil belajar matematika siswa kelas V SD IT Mutiara Insan Sorong secara umum berdasarkan observasi peneliti didapatkan bahwa sebagian besar siswa mendapatkan nilai matematika dibawah 60 , atau dalam kata lain dibawah KKM. Guru sebelum melaksanakan pembelajaran matematika, terlebih dahulu memberikan pertanyaanpertanyaan pembuka guna mengetahui konsepsi awal siswa terkait suatu konsep yang sedang dipelajari. Rendahnya hasil belajar yang didapatkan oleh siswa mengindikasikan bahwa terdapat miskonsepsi pada siswa tersebut. Pemahaman prakonsepsi yang salah diketahui setelah melakukan kegiatan wawancara kepada guru, dimana sebagian besar siswa mempunyai pemahaman yang keliru terkait konsep yang sedang dipelajari. Analisis kesalahan matematis siswa kelas V SD terkait pembelajaran Geometri yang dilakukan oleh Sutiarso \& Coesamin (2012) menunjukkan bahwa siswa mengalami kesalahan baik prosedural maupun konseptual. Analisis miskonsepsi siswa terhadap pembelajaran bangun datar segiempat yang dilakukan oleh Cahyani (2018) menunjukkan bahwa siswa dengan gaya kognitif field independent, mengalami miskonsepsi secara klasifikasional maupun teoritikal.

Berdasarkan observasi dan wawancara peneliti terhadap guru kelas V SD IT Mutiara Insan Sorong didapatkan data bahwa dalam pembelajaran matematika, secara umum siswa laki-laki lebih aktif dan memahami 
konsep lebih baik dibanding siswa perempuan dengan persentase sebesar $57,14 \%$ dimana dalam 7 kali kesempatan menjawab pertanyaan atau soal matematika siswa laki-laki menjawab sebanyak 4 kali. Keadaan tersebut berbeda dengan hasil penelitian yang dikemukakan oleh Enggar Saraswati (2015) dimana siswa perempuan didalam kelas cenderung memiliki hasil belajar yang lebih baik dibanding siswa lakilaki. Peneliti lain yang memaparkan pengaruh gender terhadap miskonsepsi pernah dilakukan oleh Utami dkk. (2017) yang menunjukkan siswa laki-laki lebih banyak mengalami miskonsepsi dibanding siswa perempuan pada pembelajaran Matematika SMA dengan persentase lakilaki sebesar $36 \%$ dan siswa perempuan sebanyak 35\%. Analisis miskonsepsi berdasarkan gender pada pembelajaran matematika kelas V SD materi bangun ruang belum pernah dilakukan sehingga penting untuk dilakukan guna mengetahui miskonsepsi, faktor penyebab miskonsepsi, serta memperoleh solusi yang tepat untuk mengatasi miskonsepsi.

Miskonsepsi pada umumnya dapat didiagnosa menggunakan jenis tes essay disertai TKJ dan wawancara (Cetin-Dindar \& Geban, 2011). Instrumen yang seringkali digunakan dalam mendiagnosa miskonsepsi yaitu tes pilihan ganda. Tes pilihan ganda lebih banyak dipilih karena mudah diaplikasikan, akan tetapi terdapat keterbatasan pada instrument essay dimana siswa terkadang memberikan jawaban benar secara kebetulan. Teknik wawancara memiliki keunggulan dapat memberikan informasi yang lebih lengkap mengenai alternatif konsep siswa dan pemahaman siswa, akan tetapi memerlukan waktu yang lama untuk mewawancarai siswa dan menggeneralisasikan konsep yang dimilikinya. Permasalahan-permasalahan tersebut dapat diatasi dengan pengembangan beberapa instrument tes dan salah satu yang digunakan peneliti dalam penelitian ini adalah tes essay disertai tingkat keyakinan jawaban (TKJ) yang dikembangkan dari metode Certainty Respons Index (Hidayat,
2014). Tes essay disertai TKJ memungkinkan peneliti dapat mengidentifikasi tingkat pemahaman konsep yang meliputi miskonsepsi serta paham dan tidaknya siswa terhadap suatu konsep yang dipelajari.

\section{METODE PENELITIAN}

Penelitian ini merupakan penelitian deskriptif dengan pendekatan penelitian kualitatif, dimana dalam penelitian ini mendeskripsikan atau menggambarkan fenomena-fenomena yang ada dan bersifat naturalistik. Peneliti mengumpulkan data mengenai suatu gejala yang terjadi akibat proses pembelajaran yang dalam hal ini miskonsepsi. Subjek dalam penelitian ini adalah siswa kelas $\mathrm{V}$ yang berjumlah 11 orang dimana siswa laki-laki sebanyak 6 orang dan siswa perempuan sebanyak 5 orang. Dalam penelitian yang akan dilakukan, jumlah siswa yang digunakan sebagai sumber data yaitu berjumlah 6 orang dimana siswa laki-laki sebanyak 3 orang dan siswa perempuan sebanyak 3 orang. Data yang akan diambil oleh peneliti berupa data terkait miskonsepsi siswa dalam menyelesaikan soal bangun ruang berdasarkan gender. Sumber data dalam penelitian ini yaitu:

\section{Sumber data literature}

Sumber data literatur merupakan sumber data yang digunakan untuk mencari kajian teori permasalahan yang akan diteliti. Dalam penelitian ini sumber data literatur berupa buku teks, hasil penelitian (skripsi), hasil karya ilmiah yang diterbitkan dalam bentuk jurnal maupun prosiding, serta sumber lain yang berkaitan dengan pembelajaran bangun ruang.

\section{Sumber data penelitian}

Yaitu sumber data yang didapatkan secara langsung oleh peneliti berupa :

\section{Data primer}

Data primer merupakan data yang didapatkan langsung dari subjek penelitian dimana dalam penelitian ini sebanyak 6 orang (3 orang laki-laki dan 3 orang perempuan) Data yang dimaksud berupa data miskonsepsi siswa dalam menyelesaikan soal 
bangun ruang berdasarkan gender yang didapatkan langsung dari siswa kelas V SD IT Mutiara Insan Sorong.

\section{Data sekunder}

Merupakan data yang didapatkan secara tidak langsung dari subjek penelitian dan bersifat sebagai pelengkap. Dalam penelitian ini data sekunder yaitu data profil sekolah oleh kepala SD IT Mutiara Insan Sorong, informasi terkait pembelajaran matematika di kelas kepada guru kelas, dan data nilai raport subjek penelitian dari guru kelasnya.

Pengumpulan data dilakukan dengan teknik tes dan non tes yang diuraikan sebagai berikut: Teknik tes yang digunakan berupa tes essay dilengkapi dengan tingkat keyakinan jawaban (TKJ). Tes essay bertujuan untuk mengidentifikasi miskonsepsi siswa pada pembelajaran bangun ruang. Wawancara dilakukan kepada siswa yang teridentifikasi mengalami miskonsepsi untuk mengetahui penyebab miskonsepsi. Tujuan wawancara yaitu untuk melengkapi dan memperjelas hasil yang diperoleh dari tes diagnosis. Jenis wawancara yang digunakan adalah wawancara bebas terpimpin, dimana wawancara ini dilakukan berdasarkan pedoman wawancara.

Data dalam penelitian ini divalidasi menggunakan teknik triangulasi. Teknik triangulasi merupakan teknik yang mencari pertemuan pada satu titik tengah informasi dari data yang terkumpul guna pengecekan dan pembandingan terhadap data yang telah ada. Teknik triangulasi yang dilakukan dalam penelitian ini yaitu teknik triangulasi metode, dimana dalam menggali kebenaran informasi miskonsepsi siswa dilakukan dengan beberapa metode yaitu, observasi, tes tertulis, dan wawancara. dengan cara mengecek data yang telah diperoleh melalui beberapa sumber. Data yang diperoleh kemudian dideskripsikan dan dikategorisasikan sesuai dengan apa yang diperoleh dari berbagai metode tersebut.

Data yang diperoleh di lapangan kemudian dianalisis berupa reduksi data, perangkuman data, serta difokuskan sesuai dengan fokus penelitian. Analisis deskriptif yaitu dengan menganalisis miskonsepsi yang terjadi pada siswa berdasarkan hasil tes essay disertai TKJ dan hasil wawancara. Tingkat pemahaman siswa digolongkan menjadi paham konsep (PK), miskonsepsi (M), dan tidak paham konsep (TPK). Kriteria penentuan subjek yang miskonsepsi (M), paham konsep (PK), dan tidak paham konsep ditunjukkan pada tabel berikut.

Tabel 1. Kriteria Penentuan Siswa yang Paham Konsep, Miskonsepsi, dan Tidak Paham Konsep

\begin{tabular}{cccc}
\hline Kriteria & \multicolumn{3}{c}{ Tingkat Keyakinan Jawaban (TKJ) } \\
\cline { 2 - 3 } Jawaban & Tidak yakin & Kurang yakin & Yakin benar \\
\cline { 2 - 3 } Jawaban & Tidak tahu & Tidak tahu & Paham konsep \\
benar & konsep & konsep & \\
\cline { 2 - 3 } Jawaban & Tidak tahu & Tidak tahu & Miskonsepsi \\
salah & konsep & konsep & \\
\hline Sumber: Hidayat, $(2014)$ & &
\end{tabular}

\section{HASIL DAN PEMBAHASAN}

Berdasarkan analisis data penelitian menggunakan cara TKJ didapatkan persentase siswa yang paham konsep, miskonsepsi, dan tidak paham konsep yang disajikan pada diagram berikut.

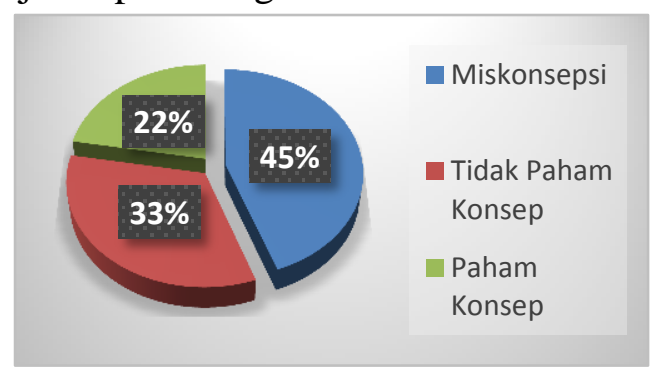

Gambar 1. Diagram persentase siswa yang paham konsep, miskonsepsi, dan tidak paham konsep

\section{Deskripsi data subjek penelitian Deskripsi Data SA}

Jawaban tertulis SA nomor 1 disajikan pada gambar 2.

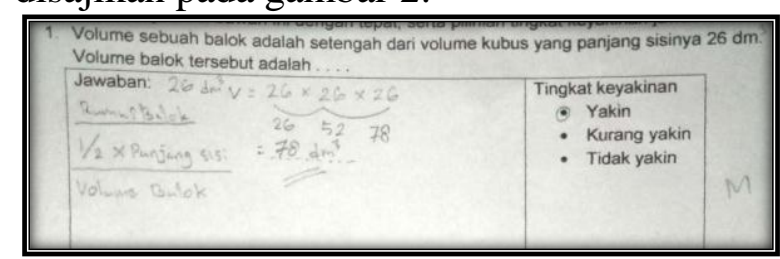

Gambar 2. Jawaban tertulis SA Nomor 1

Berdasarkan jawaban yang ditulis oleh 
SA pada gambar 2. ditunjukkan bahwa SA menuliskan jawaban akhir $78 \mathrm{dm}^{3}$ yang seharusnya jawaban pada soal nomor satu yaitu $8.788 \mathrm{dm}^{3}$ dan SA memilih tingkat keyakinan jawaban "yakin" jika jawabannya benar. Menurut metode identifikasi miskonsepsi dengan cara CRI yang telah disederhanakan menjadi TKJ sebagaimana pada tabel 1., jika subjek penelitian menuliskan jawaban yang salah akan tetapi meyakini benar jawaban tersebut maka digolongkan sebagai miskonsepsi.

Wawancara dilakukan pada SA untuk memastikan kembali jawaban yang telah ditulis dan menggali penyebab dari miskonsepsi yang dialami. Berikut adalah kutipan hasil wawancara SA terkait dengan miskonsepsi dan faktor penyebab miskonsepsi :

$P \quad$ : Menurut SA apakah yakin bahwa jawabanmu ini benar?

$S A$ : Yakin benar

$P \quad$ : Coba SA perhatikan soal nomor 1, apa yang ditanyakan?

SA : Volume balok dari $1 / 2$ volume kubus yang panjang sisinya $26 \mathrm{dm}^{3}$ adalah?

$P \quad$ : Jadi menurut SA cara menentukan volume balok dari 1/2 volume kubus tersebut bagaimana ya?

SA : Setengah kali panjang sisi-sisi

$P \quad:$ Hanya itu saja ya?

SA : Iya

$P \quad$ : Kalau cara mengalikan sisi-sisinya bagaimana ya? (sambil menunjukkan kembali jawaban SA dan meminta untuk menunjukkan cara menghitung perkaliannya)

SA : (Menghitung manual perkalian (26 $\left.\left.\mathrm{dm}^{3} \times 26 \mathrm{dm}^{3} \times 26 \mathrm{dm}^{3}\right) \times 1 / 2\right)$ sama persis seperti pada gambar 4.1.

$P \quad$ : Baik, kalau jawaban seperti ini SA dapat informasinya dari mana ya? Apakah baca buku, pernah diajarkan sama guru, atau berdasarkan pemahaman SA sendiri?

SA : Berdasarkan pemahaman saya sendiri

$P \quad$ : Baik, terus biasanya kalau belajar matematika selain di sekolah SA belajar dimana?

\section{SA : Tidak ada}

Berdasarkan petikan wawancara SA di atas, untuk soal nomor 1 SA mejelaskan konsep menentukan volume balok dimana merupakan $1 / 2$ dari volume kubus dengan cukup tepat. Akan tetapi ketika diminta untuk menghitung ulang, cara menghitungnya sama persis seperti gambar 2., dimana SA tidak mengalikan tetapi menjumlahkan sisi sisinya. Hal tersebut menunjukkan bahwa SA mengalami miskonsepsi pada konsep bangun ruang yang ditandai dengan pemahaman yang salah pada konsep perkalian walaupun sudah cukup tepat menyebutkan cara menentukan volume balok pada soal nomor 1 .

Jawaban tertulis SA nomor 2 disajikan pada gambar 3.

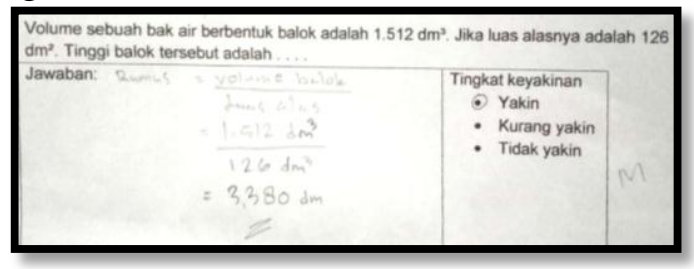

Gambar 3. Jawaban tertulis SA nomor 2

Pada soal nomor 2, jawaban yang ditulis oleh SA pada gambar 3. ditunjukkan bahwa SA menuliskan jawaban akhir 3.380 $\mathrm{dm}$ yang seharusnya jawaban pada soal nomor dua yaitu $12 \mathrm{dm}$ dan SA memilih tingkat keyakinan jawaban "yakin" jika jawabannya benar. Sebagaimana menurut metode identifikasi miskonsepsi dengan cara CRI yang telah disederhanakan menjadi TKJ pada tabel 1., maka subjek digolongkan sebagai miskonsepsi.

Selanjutnya, wawancara dilakukan pada SA untuk memastikan kembali jawaban yang telah ditulis dan menggali penyebab dari miskonsepsi yang dialami. Berikut adalah kutipan hasil wawancara SA terkait dengan miskonsepsi dan faktor penyebab miskonsepsi :

$P \quad$ : Menurut SA untuk soal nomor 2 apa sudah benar ya?

SA : Iya

$P \quad:$ Kalau soal nomor 2, apa yang ditanyakan?

SA : Tinggi balok tersebut adalah? 
$P \quad$ : Jadi menurut SA kalau menentukan tinggi balok yang diketahui volume dan luas alasnya bagaimana?

SA : Volume dibagi luas alas

$P \quad$ : Kalau cara membagi volume dengan luas alasnya bagaimana ya? (sambil menunjukkan kembali jawaban SA dan meminta untuk menunjukkan cara menghitung pembagiannya)

SA : (Menghitung manual pembagian volume dibagi luas alas)

$P \quad$ : Baik, kalau jawaban seperti ini SA dapat informasinya dari mana ya? Apakah baca buku, pernah diajarkan sama guru, atau

berdasarkan pemahaman SA sendiri?

$S A \quad$ : Pemahaman sendiri

Berdasarkan petikan wawancara SA di atas, untuk soal nomor 2 SA mejelaskan cara menentukan tinggi balok yang telah diketahui volume dan luas alasnya dengan tepat. Akan tetapi terdapat kesalahan pada proses perhitungan pembagian volume dengan luas alasnya. Pada proses perhitungan pembagian, SA kurang memahami pembagian dengan angka lebih dari 2 digit. Hal tersebut menunjukkan bahwa SA mengalami miskonsepsi pada konsep bangun ruang dimana ditandai dengan pemahaman yang salah terhadap konsep pembagian pada soal nomor 2 .

Jawaban tertulis SA nomor 3 disajikan pada gambar 4 berikut.

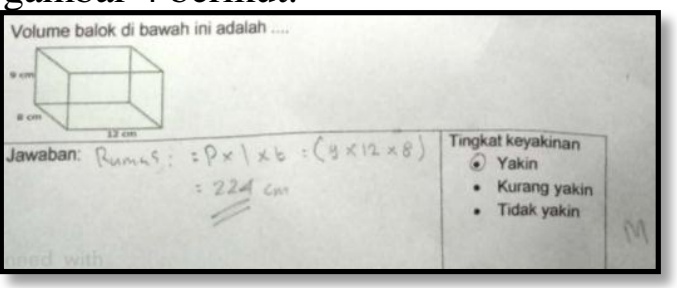

Gambar 4. Jawaban tertulis SA nomor 3

Berdasarkan gambar 4. SA menuliskan jawaban akhir yang salah, akan tetapi meyakini jawabannya secara benar. Sebagaimana metode identifikasi miskonsepsi dengan cara CRI pada tabel 1., maka disimpulkan bahwa SA mengalami miskonsepsi pada soal nomor 3. Wawancara juga dilakukan untuk mendukung dan memastikan kembali jawaban yang telah ditulis oleh SA. Berdasarkan wawancara pada soal ketiga dengan jawaban kurang lebih sama dengan soal nomor 1 dan 2, SA mengalami miskonsepsi pada proses perhitungan perkalian dan pembagian.

Sedangkan pada konsep penentuan rumus sudah cukup baik.

\section{Deskripsi Data SB}

Hasil analisis menunjukkan bahwa SB mengalami miskonsepsi pada soal nomor 3 . Berikut jawaban tertulis maupun wawancara SB pada soal nomor 3 yang teridentifikasi miskonsepsi.

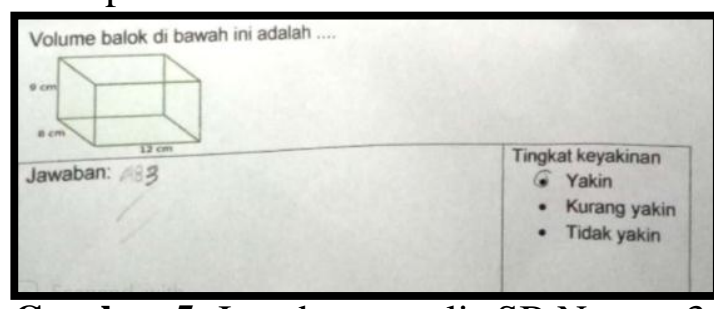

Gambar 5. Jawaban tertulis SB Nomor 3

Gambar 5. menunjukkan bahwa SB meyakini benar atas jawaban yang salah sehingga dapat digolongkan ke dalam miskonsepsi. Pada jawaban tersebut juga SB tidak menuliskan rumus untuk menentukan volume balok. Selanjutnya dilakukan wawancara untuk memastikan kembali jawaban yang telah ditulis oleh SB, serta menggali informasi terkait faktor penyebab miskonsepsinya. Berikut merupakan kutipan hasil wawancara bersama SB:

$P \quad$ : Gimana soal matematika yang tadi? Susah atau gampang ya?

$S B$ : Lumayan susah

$P \quad:$ Kalau soal nomor 3 yang ditanyakan apa ya?

$S B$ : Volume balok

$P \quad$ : Kalau diminta menentukan volume balok gimana ya caranya?

SB : Itu dikalikan angka-angka nya yang di gambar soal

$P \quad$ : Coba kamu hitung ulang untuk perkalian angka-angka yang di soal itu (sambil memberikan jawaban yang sudah ditulis sebelumnya dan selembar kertas untuk menghitung ulang)

$S B$ : (menghitung ulang perkalian dan hasilnya berbeda dengan jawaban 
pada gambar 4.6. akan tetapi jawabannya masih salah)

$P \quad:$ Jawabannya begitu ya?

$S B \quad:$ Iya

$P \quad:$ Kalau cara menghitung perkalian begitu siapa yang ajari? Atau pernah membaca buku?

\section{SB : Pikiran sendiri}

Berdasarkan wawancara bersama SB, untuk soal nomor $3 \mathrm{SB}$ mejelaskan cara menentukan volume balok jika diketahui panjang, lebar, dan tinggi dengan cukup tepat. Akan tetapi terdapat kesalahan pada proses perhitungan pembagian volume dengan luas alasnya. Pada proses perhitungan perkalian, SB kurang memahami konsep perkalian. Hal tersebut menunjukkan bahwa SB mengalami miskonsepsi pada konsep bangun ruang dimana ditandai dengan pemahaman yang salah terhadap konsep perkalian pada soal nomor 3 .

\section{Deskripsi Data SC}

Soal yang dialami miskonsepsi oleh SC berdasarkan hasil analisis miskonsepsi yaitu soal nomor 1. Jawaban tertulis SC untuk soal nomor 1 dapat dilihat pada gambar 6 .

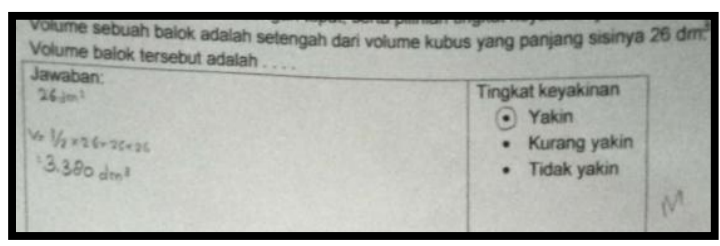

Gambar 6. Jawaban tertulis SC nomor 1

Pada gambar 6. ditunjukkan bahwa SC yakin dengan hasil perhitungan yang salah. Seharusnya nilai dari $1 / 2$ dikali panjang sisi yaitu sebesar $8.788 \mathrm{dm}^{3}$ sehingga sesuai dengan tabel 3.1. dapat digolongkan dalam miskonsepsi. Pada jawaban tertulis gambar 6 . SC telah menuliskan cara menentukan volume dengan soal yang diketahui bahwa volume balok merupakan $1 / 2$ dari volume

kubus. Untuk memperjelas jawaban SC serta menggali penyebab miskonsepsi, dilakukan wawancara yang diperlihatkan pada kutipan wawancara berikut:

$P \quad$ : Kalau soal nomor 1 yang ditanyakan apa ya?

SC : Volume balok?
$P \quad$ : Kalau diminta menentukan volume balok dan sudah diketahui pada soal bahwa volume balok merupakan setengah dari volume kubus dan diketahui panjang sisi, gimana ya caranya?

$S C$ : Setengah dikali panjang sisi

$P \quad$ : Coba tolong hitung ulang untuk menentukan volume balok soal nomor 1 (sambil memberikan jawaban yang sudah ditulis sebelumnya dan selembar kertas untuk menghitung ulang)

$S C$ : (menghitung ulang perkalian dan hasilnya sama seperti jawaban SC pada gambar 4.7.)

$P \quad$ : Jawabannya begitu ya?

$S C:$ Iya

$P \quad$ : Kalau cara menghitung perkalian begitu siapa yang ajari? Atau pernah membaca buku?

SC : Pikiran sendiri

Berdasarkan petikan wawancara SC di atas, untuk soal nomor 1 SC mejelaskan konsep menentukan volume balok dimana merupakan $1 / 2$ dari volume kubus dengan cukup tepat. Akan tetapi ketika diminta untuk menghitung ulang masih belum tepat cara kerja perkalian yang dimaksud pada soal nomor 1. Hal tersebut menunjukkan bahwa SA mengalami miskonsepsi pada konsep bangun ruang yang ditandai dengan pemahaman yang salah pada konsep perkalian walaupun sudah cukup tepat menyebutkan cara menentukan volume balok pada soal nomor 1.

\section{Deskripsi Data SF}

Berdasarkan hasil penelitian, SF mengalami miskonsepsi pada ketiga nomor soal. Berikut deskripsi masing-masing soal yang dialami miskonsepsi. Jawaban tertulis SF untuk soal nomor 1 sebagaimana dicantumkan pada gambar 8 .

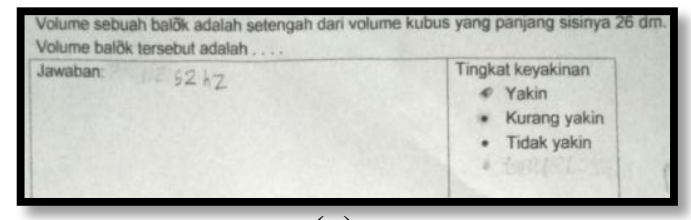

(a) 


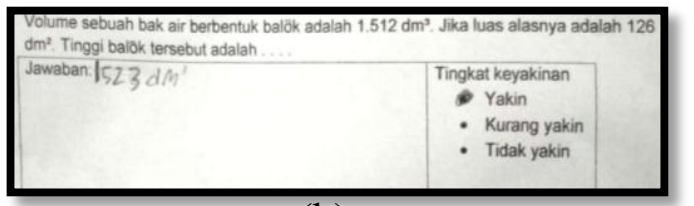

(b)

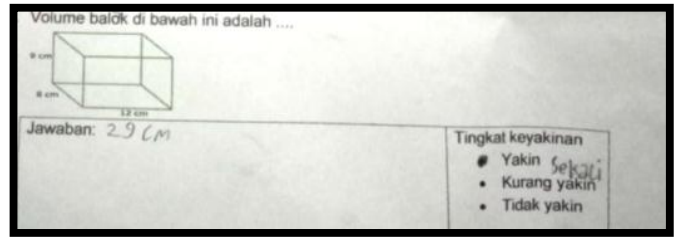

(c)

Gambar 8. (a) Jawaban tertulis soal nomor 1, (b) Jawaban tertulis nomor 2, dan (c) Jawaban tertulis nomor3

Berdasarkan gambar 4.8. SF memberikan jawaban tanpa menuliskan cara mendapatkan jawaban tersebut. Ketiga jawaban yang tertulis salah, akan tetapi SF meyakini bahwa jawabannya benar. Berdasarkan tabel 3.1. maka pada ketiga jawaban tersebut dapat digolongkan ke dalam miskonsepsi. Wawancara selanjutnya dilakukan untuk memastikan kembali jawaban SF serta faktor penyebab miskonsepsi. Berikut kutipan wawancara SF terkait jawaban soal yang telah dituliskan:

$P \quad$ : Bagaimana dengan soal tadi? Mudah atau susah ya?

SF : Lumayan susah

$P \quad$ : Dari tiga soal yang dikerjakan kamu yakin sudah benar semua?

SF : Iya

$P \quad$ : Kenapa jawaban yang kamu tulis tidak mencantumkan langkahlangkahnya?

SF : Kerjakan di kertas

$P \quad:$ Boleh lihat kertas cakarannya?

$S F \quad:$ Sudah dibuang

$P \quad:$ Kalau begitu coba dikerjakan ulang soal nomor 1 nya. Itu yang ditanyakan apa ya?

SF : Volume balok

$P \quad$ : Untuk mencari volume balok yang diketahui bahwa volumenya setengah kubus berarti gimana caranya?

$S F \quad:$ Tidak bisa

$P \quad$ : Terus jawaban yang ditulis di kertas darimana?

SF : Cuma tulis saja

$P \quad:$ Kalau nomor 2 dan 3 bagaimana ya?

SF : Sama
$P \quad$ : Kalau tentang materi ini bu guru sudah mengajarkan atau belum ya?

SF : Sudah tapi masih bingung

Berdasarkan petikan wawancara SF di atas, untuk soal nomor 1 sampai dengan $3 \mathrm{SF}$ menyampaikan bahwa belum memahami konsep tentang bangun ruang, hal tersebut ditandai dengan tidak dapat menentukan volume dari balok seperti yang ditanyakan di soal. Berdasarkan wawancara dapat dipastikan bahwa SF belum memahami konsep tentang bangun ruang, sehingga tidak digolongkan sebagai miskonsepsi.

Sebanyak 6 orang subjek penelitian (siswa) yang berasal dari kelas V SD IT Mutiara Insan Sorong diuji untuk mengidentifikasi miskonsepsi siswa pada konsepsi yang terdapat pada materi bangun ruang. Tes diagnosis dan wawancara dilakukan untuk mendapatkan data dalam penelitian ini. Penyusunan instrumen tes diagnosis dilakukan berdasarkan validitas isi melalui validasi ahli (expert judgement) sehingga sebanyak 3 soal konsep yang dijadikan sebagai instrumen tes dinyatakan valid dan dapat digunakan sebagai instrumen penelitian. Soal tes diagnostik berupa soal essay disertai uraian jawaban dan tingkat keyakinan jawaban (TKJ).

Tes diagnosis dilakukan pada tanggal 21 Oktober 2015 dengan alokasi waktu 30 menit. Analisis data hasil penelitian kemudian dilakukan dengan menganalisis jawaban tertulis maupun wawancara dan kriteria TKJ siswa sebagaimana terdapat pada tabel 3.1. Berdasarkan deskripsi dan analisis data miskonsepsi siswa SD IT Mutiara Insan, dapat diambil kesimpulan bahwa secara umum siswa sebagai subjek penelitian sebanyak 6 orang dengan konsep yang diujikan sebanyak 3 soal mengalami miskonsepsi dengan rata-rata persentase sebesar $45 \%$. Sebanyak $22 \%$ lainnya memahami konsep dengan baik, sedangkan $33 \%$ lainnya tidak paham konsep. Berdasarkan gender, siswa laki-laki sebagai subjek penelitian teridentifikasi miskonsepsi sebanyak 1 orang, sedangkan semua siswa perempuan teridentifikasi miskonsepsi.

Hasil analisis berdasarkan gender yang 
telah dilakukan, berbeda dengan penelitian sebelumnya oleh Utami dkk., (2017) dimana persentase siswa laki-laki yang mengalami miskonsepsi lebih besar dibandingkan siswa perempuan pada pembelajaran kimia SMA. Miskonsepsi yang terjadi di SD IT Mutiara Insan berdasarkan gender disebabkan oleh pemikiran asosiatif siswa sendiri, hal ini diperkuat dengan hasil wawancara bersama guru kelas V SD IT Mutiara Insan yang menyatakan bahwa proses pembelajaran di kelas sudah memaksimalkan segala sumber daya yang ada untuk meminimalisir

kesalahan pemahaman yang terjadi pada siswa, akan tetapi masih terdapat beberapa siswa yang belum maksimal pemahamannya. Proses pembelajaran matematika di kelas juga tidak hanya terfokus pada siswa tertentu maupun jenis kelamin tertentu, sehingga berbeda dengan fenomena permasalahan pendidikan terkait gender yang dikemukakan oleh Yuniarti, (2014) dimana sebagian besar kebiasaan guru dalam mengajar lebih terfokus pada jenis kelamin tertentu.

Berdasarkan deskripsi dan analisis data penelitian didapatkan hasil bahwa dari empat siswa yang teridentifikasi miskonsepsi menggunakan analisis TKJ, hanya 3 orang siswa yang benar-benar miskonsepsi setelah dicek kembali dengan wawancara. Satu orang siswa yang teridentifikasi miskonsepsi dengan analisis TKJ setelah diwawancara didapatkan informasi bahwa siswa tersebut hanya mengarang jawaban dan memilih tingkat keyakinan "yakin", sehingga dapat disimpulkan bahwa siswa tersebut tidak paham konsep.

Miskonsepsi yang dialami siswa SD IT

Mutiara Insan Sorong terdapat pada proses perkalian dan pembagiannya bukan pada konsep penentuan volume balok (materi bangun ruang), hal ini ditandai dengan jawaban tertulis yang menyertakan rumus penentuan volume balok dengan tepat. Miskonsepsi pada proses perhitungan perkalian dan pembagian diperkuat dengan jawaban wawancara oleh subjek penelitian, dimana ketika menghitung ulang soal yang teridentifikasi miskonsepsi, siswa tidak dapat menghitungnya dengan benar. Sejalan dengan teori belajar konstruktivisme, siswa dalam hal ini membangun konsepnya sendiri ketika penanaman konsep berlangsung di dalam kelas, sehingga terkadang konsep yang dibangun siswa berbeda dengan konsep sebenarnya dan jika tidak segera diluruskan konsep tersebut akan menimbulkan miskonsepsi.

Siswa yang teridentifikasi miskonsepsi menyatakan bahwa hanya belajar matematika di sekolah tanpa ada tambahan pembelajaran matematika di luar sekolah seperti belajar bersama orang tua maupun melalui bimbingan belajar (bimbel), sehingga konsep yang dibangun tidak sempat diluruskan dan menjadi penyebab miskonsepsi. Oleh karena itu perlu bagi setiap guru untuk mengetahui miskonsepsi yang terjadi pada peserta didiknya, sehingga paling tidak dapat meluruskan konsep yang dibangun serta menyiapkan strategi khusus agar konsep yang diajarkan dapat dipahami dengan baik oleh siswa.

\section{KESIMPULAN}

Berdasarkan penelitian yang telah dilakukan, dapat disimpulkan bahwa :

Miskonsepsi teridentifikasi pada semua konsep yang diuji, sedangkan subjek yang mengalami miskonsepsi sebanyak 3 orang dari 6 orang siswa yang dijadikan subjek penelitian.

Berdasarkan gender, miskonsepsi terjadi pada siswa perempuan sedangkan siswa laki-laki tidak teridentifikasi miskonsepsi akan tetapi lebih pada tidak memahami konsep.

Miskonsepsi terjadi pada proses berhitungan perkalian dan pembagian, sedangkan pada konsep bangun ruang tidak terjadi miskonsepsi.

Miskonsepsi yang dialami siswa disebabkan oleh prakonsepsi siswa, pemikiran asosiatif siswa, pengalaman belajar matematika yang rendah, serta kurangnya penekanan guru pada materi tertentu.

\section{DAFTAR RUJUKAN}

Asbar. (2017). Analisis Miskonsepsi Siswa pada 
Persamaan dan Pertidaksamaan Linear Satu Variabel dengan Menggunakan Three Tier Test. Skripsi Tidak Dipublikasikan.

Cahyani, F. N. I. (2018). Analisis Miskonsepsi Siswa Materi Bangun Datar Segiempat dibedakan dari Gaya Kognitif Siswa. Skripsi Tidak Dipublikasikan.

Cetin-Dindar, A., \& Geban, O. (2011). Development of a three-tier test to assess high school students' understanding of acids and bases. Procedia - Social and Behavioral Sciences, 15, 600-604. https://doi.org/10.1016/j.sbspro.2011.03.14 7

Enggar saraswati. (2015). Perbedaan Hasil Belajar Siswa Laki-Laki dan Perempuan dalam Mata Pelajaran Matematika Kelas III Semester 2 Materi Sudut dan Pecahan di SD Negeri Se-Desa Caturharjo, Kecamatan Sleman, Kabupaten Sleman. Skripsi Tidak Dipublikasikan.

Farida, A. (2016). Analisis miskonsepsi siswa pada persamaan dan pertidaksamaan linear satu variabel dengan menggunakan three tier test, (Knpmp I), 286-295.

Fibrianto, A. S. (2016). Kesetaraan Gender Dalam Lingkup Organisasi Mahasiswa Universitas Sebelas Maret Surakarta Tahun 2016. Jurnal Analisa Sosiologi, 5(1), 10 27.

Hamka, D., Sobri, M., \& Rizal, S. (2013). Aplikasi Kamus Inggris - Indonesia Indonesia - Inggris Pada Platform Android. Universitas Bina Darma.

Hidayat, F. A. (2014). analisis miskonsepsi siswa kelas XA pada materi struktur atom di SMA muhammadiyah kota jayapura tahun ajaran 2013/2014. Skripsi Tidak Dipublikasikan.

Pesman, H., \& Eryilmaz, A. (2010).
Development of a three-tier test to assess misconceptions about simple electric circuits. Journal of Educational Research, 103(3), 208-222. https://doi.org/10.1080/0022067090338300 2

Purba, J. P. \& Depari, G. (2008). Konsep Dalam Rangkaian Listrik Menggunakan Certainty of Response Index Dan Interview. Artikel.

Rosmalia, L. P. (2016). Miskonsepsi Pembelajaran Matematika Kelas IV Semester II di Sekolah Dasar. Skripsi Tidak Dipublikasikan, 2016.

Sutiarso, S., \& Coesamin, M. (2012). Identifikasi Kesalahan Matematis Siswa Kelas V Sekolah Dasar dalam Geometri. Pendidikan MIPA, 14(1), 33-38.

Tayubi, Y. R. (2005). Identifikasi Miskonsepsi Pada Konsep-Konsep Fisika Menggunakan Certainty of Response Index (CRI). Jurnal UPI, 24(3), 4-9. https://doi.org/10.1093/pasj/65.2.47

Utami dkk., D. R. (2017). Analisis Pengaruh Gender Terhadap Miskonsepsi Siswam SMAN di Kota Depok dengan Menggunakan Tes Diagnostik Two-Tier. Prosiding Seminar Nasional Pendidikan FKIP UNTIRTA, 93-102.

Yuniarti, D. Y. (2014). Pengaruh Sikap dan Gender Terhadap Prestasi Belajar Bahasa Indonesia pada Siswa SMP Negeri Kelas VII di Kecamatan Sleman Yogyakarta 2013/2014. Skripsi Tidak Dipublikasikan. Retrieved from http://eprints.uny.ac.id/20691/1/Rohmah Dwi Yuniarti 09201244082.pdf 